\title{
Regional Trends in Dietary Intake in Japan: the 2003 2017 National Health and Nutrition Survey
}

\author{
Emiko Okada, Chika Okada, Mai Matsumoto and Hidemi Takimoto
}

Department of Nutritional Epidemiology and Shokuiku, National Institute of Health and Nutrition, National Institutes of Biomedical Innovation, Health and Nutrition

doi:10.5264/eiyogakuzashi.78.S16

\begin{abstract}
Objective: There are regional health disparities in Japan regarding the physical condition and lifestyle as demonstrated in the gaps among prefectures. However, no regional annual trends have been reported. This study investigated the regional trends in dietary intake among Japanese adults.

Methods: Overall, 140,817 Japanese participants (64,773 men and 76,044 women) aged $\geq 20$ years, registered in the 2003 2017 National Health and Nutrition Survey were included. The dietary survey was conducted with a semi-weighted household-based dietary record on a single day. The 47 prefectures were regrouped into 12 regions. Age-adjusted mean intakes of energy, carbohydrate, fat, protein, salt, vegetables, and fruits by region were estimated using a regression model, according to the survey years. Trend analyses from 2003 to 2017 were performed using the Joinpoint Regression Program.

Results: Significant decreases in carbohydrate and salt intake were noted in all regions, whereas fat intake showed a significant change in trend with annual increases. Protein intake decreased in approximately half and fruit intake decreased in two thirds of the regions. No changes in trend in energy and vegetable intake were observed in most regions, although a declining annual trend was observed in some regions.

Conclusions: In Japan, annual trend in intakes of energy, protein, vegetables, and fruits differed among regions from 2003 to 2017. These results may be attributed to the differences in health and nutrition policies between local governments. Regional trends in dietary intake among Japanese need to be monitored continuously to develop health and nutrition policies for local governments.
\end{abstract} Jpn. J. Nutr. Diet., Vol.78 Supplement S16-S26 (2020)

Key words: National Health and Nutrition Survey, dietary intake, dietary assessment, Japan

\section{Introduction}

The National Health and Nutrition Survey (NHNS) in Japan reports annual trends in dietary intake, physical condition, and lifestyle ${ }^{1)}$. Nutrient and food intake among the Japanese have changed with changes in lifestyle including dietary habits in Japan ${ }^{2}$. In the Japanese national health policy, Health Japan 21 (second term), decreasing the salt intake and increasing the vegetable and fruit intake are among the goals for improving nutrition and dietary habits ${ }^{3}$. To achieve these goals, the efforts of both the national and local governments are important. The 1947 1956 surveys were conducted in urban and rural area, or urban and district by population size, and the results were compared by regions ${ }^{4)}$. A report on the regional annual trends in dietary intake in Japan from 1966 to 1988 have shown that the salt intake in the Tohoku region was greatly decreased ${ }^{5}$. In recent years, dietary intake status among the different prefectures have been reported in the 2012 and 2016 surveys $^{6,7)}$. Dietary intake values were adjusted for age in each prefecture, then divided into quartiles and compared between the highest and the lowest quartile ${ }^{7}$. In the 2016 survey, significant differences in the vegetable intake and salt intake between the highest and lowest groups were observed ${ }^{7}$. In the 2016 survey, there were significant differences in vegetable intake and salt intake between the highest and lowest groups ${ }^{7}$. There are regional health disparities in Japan, as demonstrated in the gap among prefectures regarding dietary intake. Based on the 2016 survey, pre-

Corresponding Author: Hidemi Takimoto. Department of Nutritional Epidemiology and Shokuiku, National Institute of Health and Nutrition, National Institutes of Biomedical Innovation, Health and Nutrition, 1-23-1 Toyama, Shinjuku-ku, Tokyo 162-8636, Japan Tel: +81-03-3203-5724 Fax: +81-03-3207-7206 E-mail: thidemi@nibiohn.go.jp 
fectures in the highest quartile of vegetable intake belonged to the north-eastern part of Honshu island. However, no regional annual trends have been reported in recent years. To formulate a regional health promotion plan, it is necessary to assess annual trends in dietary intake by region.

The present study aimed to investigate the regional trends in dietary intake among Japanese adults using nationwide data from the 2003 2017 NHNS. In this study, we focused on changes in the intake of macronutrients such as energy, carbohydrate, fat, and protein and intake of salt, vegetable, and fruit according to regions.

\section{Subjects and Methods}

\section{National Health and Nutrition Survey data}

The NHNS is a cross-sectional survey that has been conducted annually since 1947 (between October and December each year) by the Ministry of Health, Labour and Welfare in Japan. Details of the survey design have been provided elsewhere ${ }^{2,8)}$. Briefly, the NHNS uses a stratified cluster sampling design across 47 prefectures. Iwate, Miyagi, and Fukushima Prefectures were excluded from the 2011 survey due to the Great East Japan Earthquake while Kumamoto Prefecture was excluded from the 2016 survey due to the Kumamoto Earthquake. Census enumeration areas were drawn from each prefecture and residents aged $\geq 1$ year in all households were selected from 300 selected census enumeration areas from 2003 2017. The exceptions were the 2004, 2012, and 2016 surveys, which were conducted in 298 areas (2 areas in Niigata Prefecture were excluded due to the Mid Niigata Prefecture Earthquake), 475 areas, and 462 areas, respectively, out of the survey areas eligible for inclusion. Household response rate for each survey year was approximately $43.1 \sim 83.2 \%$ from 2003 to 2017 , and the mean response rate for households was $63.8 \%$. The NHNS comprises three surveys: the dietary intake survey (a selfadministered questionnaire including questions on the household members, meal patterns, daily step counts, and dietary records); the lifestyle survey (a self-administered questionnaire including questions on smoking status, alcohol intake, and sleep time); and a physical examination (measurement of height, weight, abdominal circumference, and blood pressure; blood tests; and a medical interview). Based on official application procedures under Article 33 of the Statistics Act, we obtained approval from the Ministry of Health, Labour and Welfare, Japan to use individual-level data from the NHNS for this study. In accordance with the Ethical Guidelines for Epidemiological Research ${ }^{9)}$, our study was exempted from the application of these guidelines as only anonymized data were used.

\section{Study participants}

A total of 140,817 participants $(64,773$ men and 76,044 women) aged $\geq 20$ years were included in the analysis, excluding those who did not complete the dietary intake survey. We analyzed the results of the present study using the NHNS as a simple random sample.

\section{Dietary assessment}

The dietary intake survey, which applies a semiweighted household-based dietary record, was conducted on a single day excluding Sundays and public holidays. The dietary intake survey was annually conducted in November, except for 2012 (between October 25 and December 7) and 2016 (between October 1 and November 30). Trained interviewers visited each household to explain the method for generating the dietary records before the survey. Dietary records were weighed by taking an inventory of all the foods and beverages consumed, food waste, leftovers, and foods consumed away from home, in the household. For shared dishes within the household, the approximate proportions of each food were assigned to individual household members to estimate food intake for individuals. Interviewers checked for any missing information and errors during household visits to collect the dietary records. Nutrient intakes were calculated on the basis of the Standard Tables of Food Composition in Japan ( $^{\text {th }}$ edition for the 2003 2004 survey, $5^{\text {th }}$ revised and enlarged edition for the 2005 2010 survey, and the 2010 edition for the 2011 2017 survey).

\section{Statistical analysis}

All statistical analyses were performed for the following 12 regions: Hokkaido, Tohoku, Kanto I, Kanto II, Hokuriku, Tokai, Kinki I, Kinki II, Chugoku, Shikoku, Kita-Kyusyu, and Minami- Kyusyu were listed in order of their locations in Japan from north to south. Kanto I includes the Tokyo metropolitan area, and Kinki I includes Osaka. Ageadjusted means and standard errors of energy, carbohydrate, fat, protein, salt, vegetable, and fruit intakes were 
estimated using the regression model according to the survey years. Carbohydrate (not including alcohol), fat, and protein (\%energy) values were calculated using the following formulae:

$$
\begin{aligned}
& \text { Carbohydrate }(\% \text { energy) }= \\
& \frac{\text { carbohydrate intake }(\mathrm{g}) \times 4(\mathrm{kcal} / \mathrm{g})}{\text { total energy intake }(\mathrm{kcal})} \times 100
\end{aligned}
$$

Fat (\%energy) = $\frac{\text { fat intake }(\mathrm{g}) \times 9(\mathrm{kcal} / \mathrm{g})}{\text { total energy intake }(\mathrm{kcal})} \times 100$

$$
\begin{aligned}
& \text { Protein }(\% \text { energy) }= \\
& \frac{\text { protein intake }(\mathrm{g}) \times 4(\mathrm{kcal} / \mathrm{g})}{\text { total energy intake }(\mathrm{kcal})} \times 100
\end{aligned}
$$

Salt, vegetable, and fruit ( $\mathrm{g} / 1,000 \mathrm{kcal})$ was calculated by the following formula using the density method:

Salt, vegetable, or fruit $(\mathrm{g} / 1,000 \mathrm{kcal})=$

$$
\frac{\text { salt, vegetable, or fruit intake }(\mathrm{g})}{\text { total energy intake }(\mathrm{kcal})} \times 1,000
$$

Age adjustment was performed according to six age categories (20 29, 30 39, 40 49, 50 59, 60 69, and $\geq 70$ years), and the standard population on the 2010 census was used $^{10)}$. The weight for participants in each prefecture was calculated by dividing the total number of households during the prior 3 years in each prefecture by that in the 2012 and 2016 surveys. The details of weighing has been described elsewhere ${ }^{6)}$. The trend analyses were performed using the Joinpoint Regression Program (Joinpoint Regression software, version 4.2; National Cancer Institute, USA [https://www.surveillance.cancer.gov/joinpoint]). Joinpoint regression analysis uses statistical crite- ria to determine the minimum number of linear segments needed to describe a trend and to determine the annual percentage change (APC) in each segment. The Monte Carlo permutation method was used to test if a change in the trend is statistically significant ${ }^{11)}$. Differences were considered statistically significant at $p<0.05$.

\section{Results}

The trends in energy intake (kcal), carbohydrate (\%energy), fat (\%energy), and protein (\%energy) intake, adjusted for age category are shown in Supplement Tables 1. Supplement Tables 2 shows the trends in intake of salt, vegetable, and fruit ( $\mathrm{g} / 1,000 \mathrm{kcal})$ adjusted for age category. Figure 1 7 shows some regions with characteristic by the trends in dietary intake. Joinpoint regression analysis identified a change in the trend from 2003 to 2017. No change in the trend of energy intake was observed in most regions; however, Kanto II, Hokuriku, and Minami-Kyusyu showed significant decreases in APC of $0.2 \%, 0.3 \%$, and $0.3 \%$ from 2003 to 2017, respectively. Between 2008 and 2015 , there was a year when carbohydrate intake decreased in all regions, with APC decreasing significantly by $0.2 \sim 2.7 \%$. There was a significant change in the trend of fat intake, with annual increases of $0.8 \sim 1.2 \%$ from 2003 to 2017. In Hokkaido, Tohoku, Kanto I, Kanto II, Tokai, and Kinki I, there were significant decreases in the APC of protein intake of $0.5 \%$ (from 2003 to 2017), 0.6\% (from 2003 to 2010 ), $0.5 \%$ (from 2003 to 2011), 0.8\% (from 2003 to 2010), $0.2 \%$ (from 2003 to 2017), and $0.2 \%$ (from 2003 to

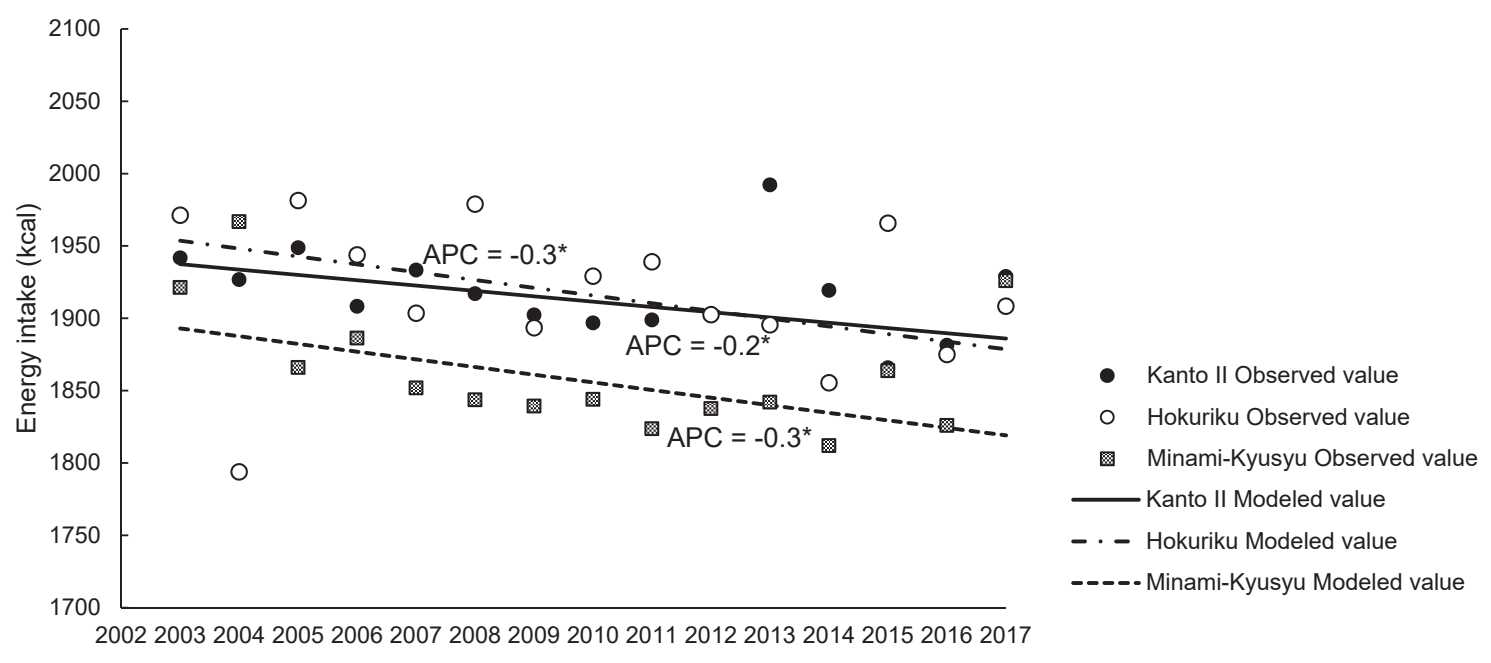

Figure 1 Trends in energy intake (kcal) adjusted for age category in Kanto II, Hokuriku and Minami-Kyusyu from 2003 to 2017. ${ }^{*} p<0.05$. 


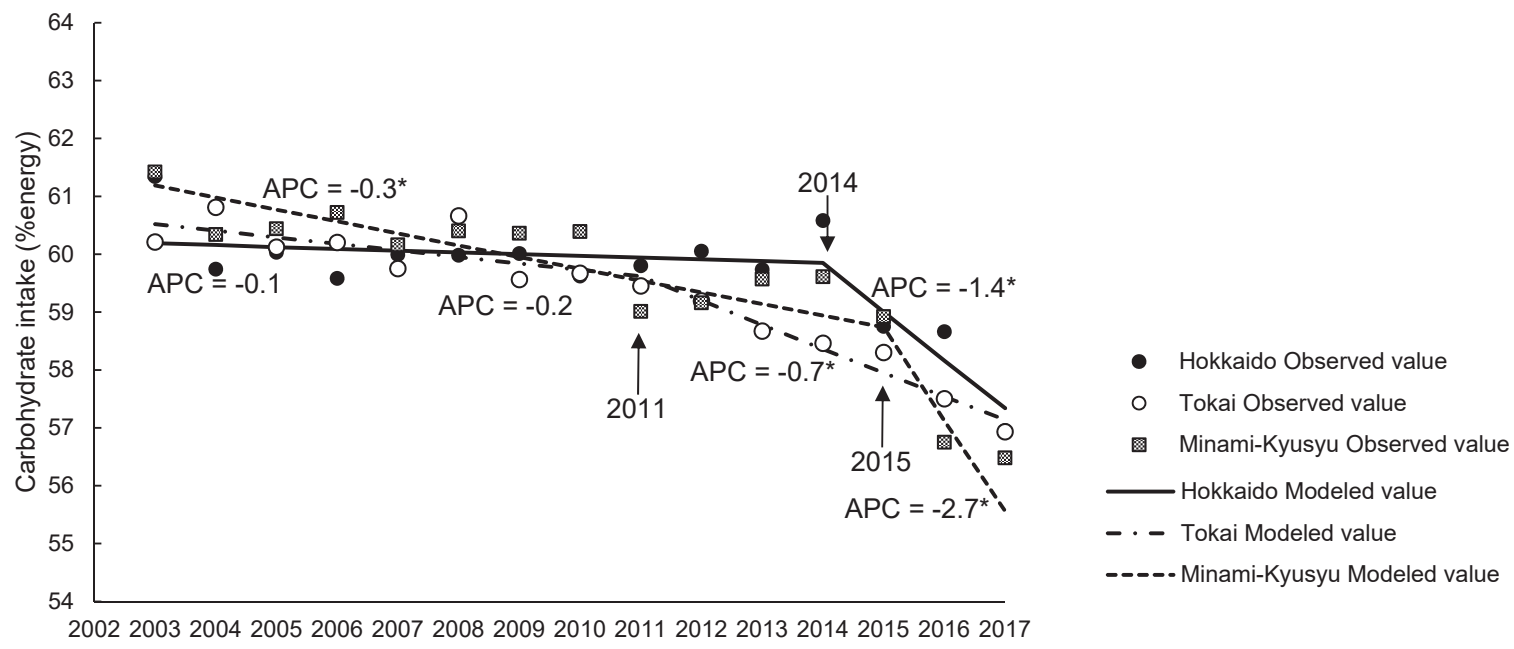

Figure 2 Trends in carbohydrate intake (\%energy) adjusted for age category in Hokkaido, Tokai and Minami-Kyusyu from 2003 to $2017 .{ }^{*} p<0.05$.

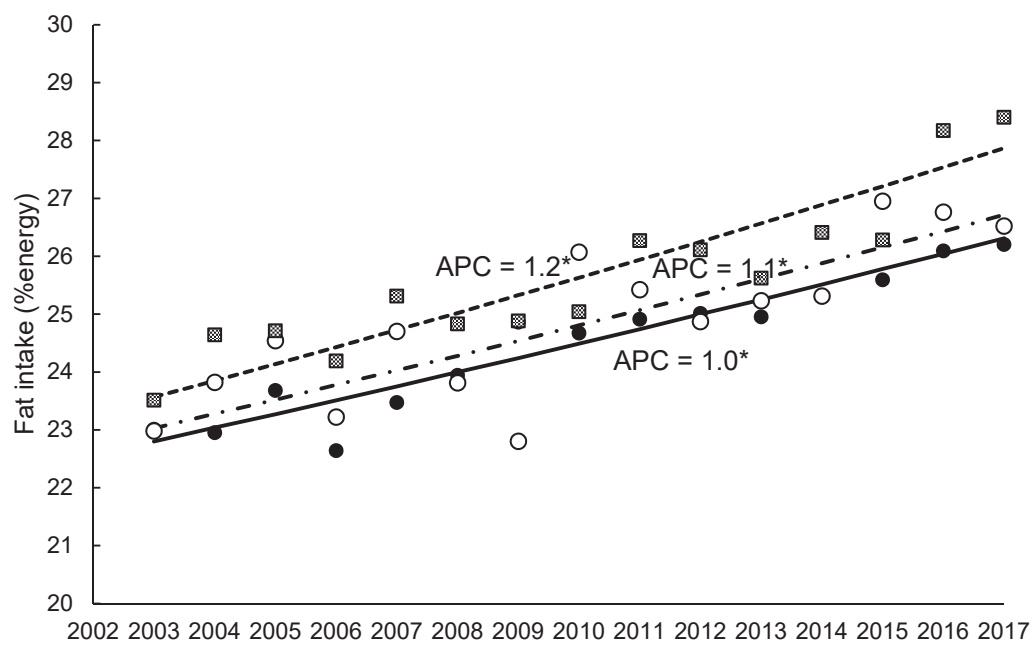

- Hokuriku Observed value

○ Shikoku Observed value

Minami-Kyusyu Observed value

- Hokuriku Modeled value

- - Shikoku Modeled value

---- Minami-Kyusyu Modeled value

Figure 3 Trends in fat intake (\%energy) adjusted for age category in Hokuriku, Shikoku and Minami-Kyusyu from 2003 to $2017 .{ }^{*} p<0.05$.

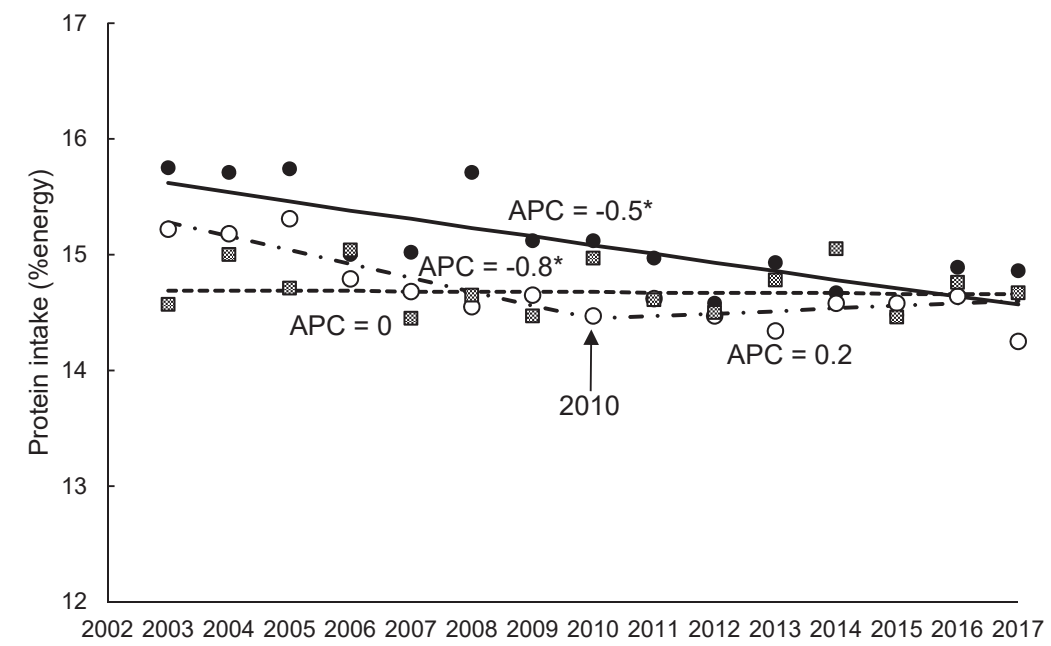

- Hokkaido Observed value

- Kanto II Observed value

圆 Chugoku Observed value

- Hokkaido Modeled value

- - Kanto II Modeled value

-----Chugoku Modeled value

Figure 4 Trends in protein intake (\%energy) adjusted for age category in Hokkaido, Kanto II and Chugoku from 2003 to 2017 . ${ }^{*} p<0.05$. 


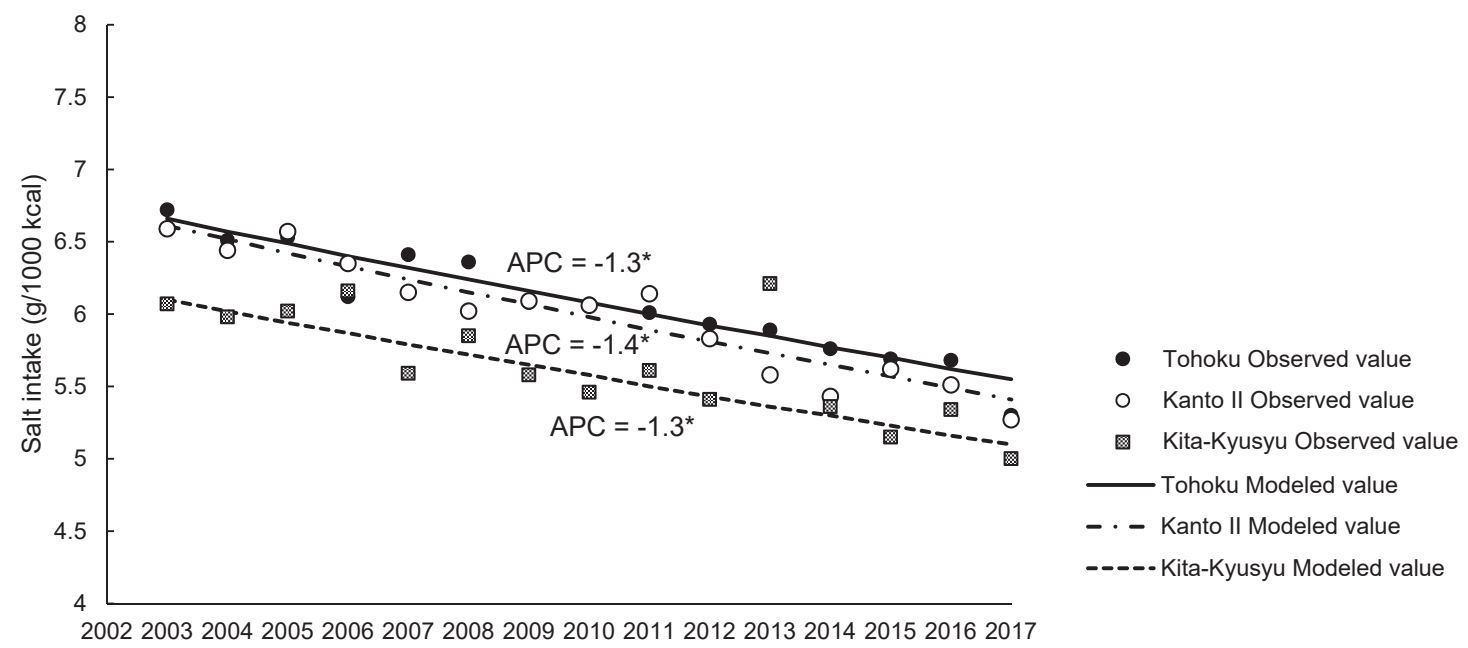

Figure 5 Trends in salt intake (g/1,000 kcal) adjusted for age category in Tohoku, Kanto II and Kita-Kyusyu from 2003 to $2017 .{ }^{*} p<0.05$.

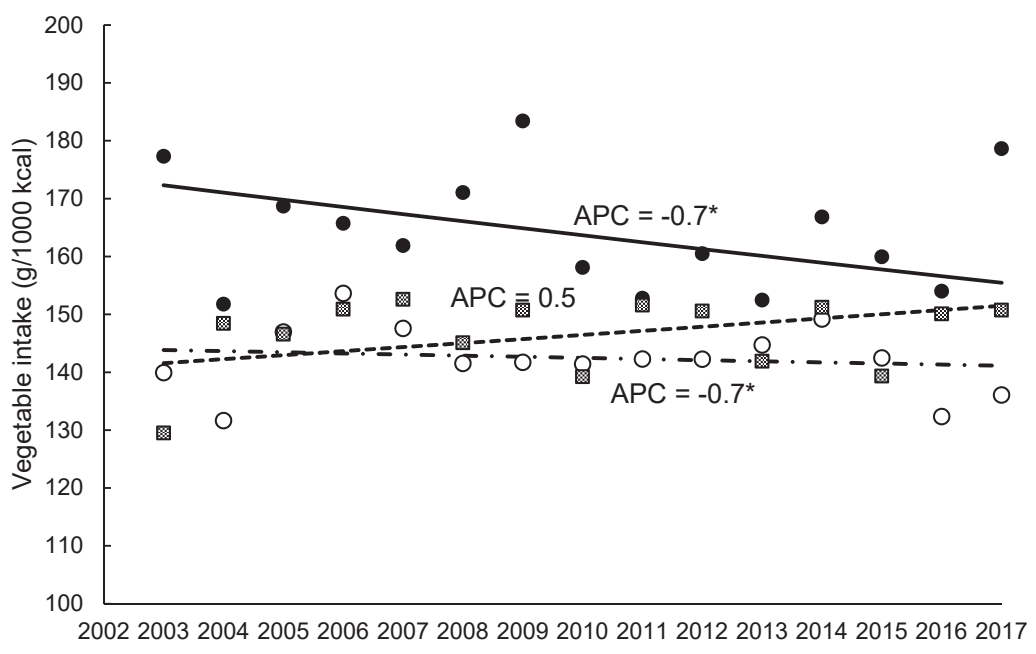

- Hokuriku Observed value

- Kinki II Observed value

Shikoku Observed value

Hokuriku Modeled value

- - Kinki II Modeled value

-.... Shikoku Modeled value

Figure 6 Trends in vegetable intake $(\mathrm{g} / 1,000 \mathrm{kcal})$ adjusted for age category in Hokuriku, Kinki II and Shikoku from 2003 to $2017 .{ }^{*} p<0.05$.

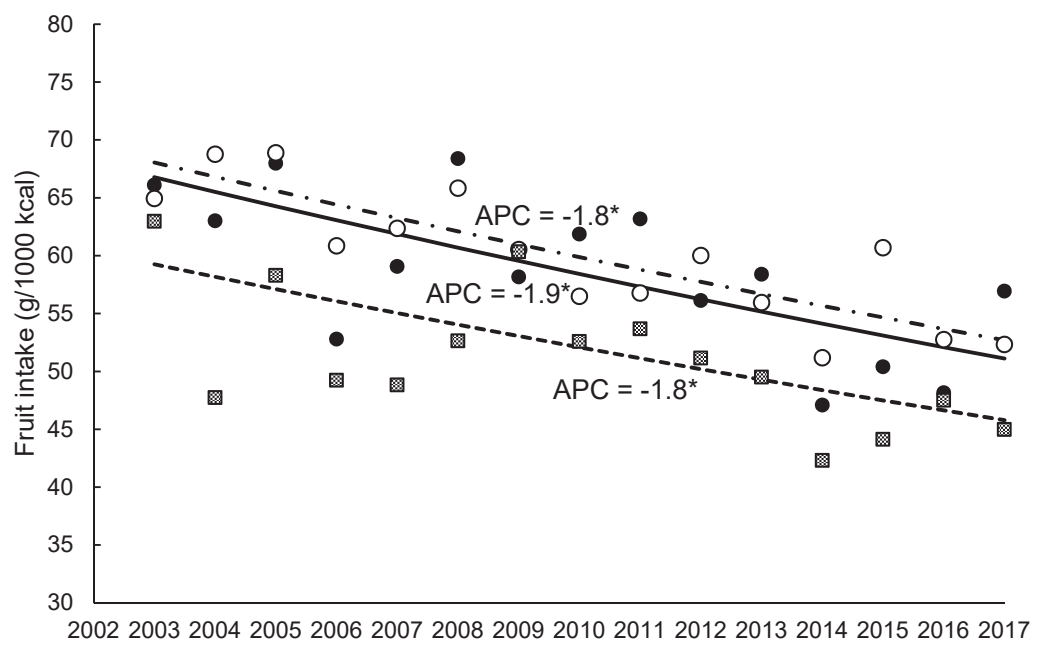

- Hokkaido Observed value

- Kanto I Observed value

M Minami-Kyusyu Observed value

Hokkaido Modeled value

- - Kanto I Modeled value

--.-.- Minami-Kyusyu Modeled value

Figure 7 Trends in fruit intake ( $\mathrm{g} / 1,000 \mathrm{kcal})$ adjusted for age category in Hokkaido, Kanto I and Minami-Kyusyu from 2003 to $2017 .{ }^{*} p<0.05$. 
2017), respectively. There was a significant change in the trend of salt intake, with annual decreases in APC of $0.9 \sim 1.4 \%$ in all regions from 2003 to 2017 . No change in the trend of vegetable intake was observed in most regions; however, Hokuriku and Kanto II showed significant decreases of $0.7 \%$ in APC in each year from 2003 to 2017, respectively. There were significant decreases in the APC of fruit intake of $1.2 \sim 1.9 \%$ in two-thirds of the regions except for Kanto II, Hokuriku, Kinki II, and Kita-Kyusyu. As the result of stratified analysis by sex, similar increasing or decreasing trends of dietary intake according to regions in Japan were observed (data not shown).

\section{Discussion}

We investigated the regional trends in dietary intake among Japanese adults using the nationwide NHNS data from 2003 to 2017. To our knowledge, this study is the first to investigate the regional trends in dietary intake in Japan in recent years.

No change in trend in energy intake was observed in most regions in the last 15 years (from 2003 to 2017), but slight decreases in trend were observed in Kanto II, Hokuriku, and Minami-Kyusyu. The energy intake has decreased nationwide from 1966 to $1988^{5)}$, and the trend in energy intake has changed in recent years. There was a decreasing trend in carbohydrate intake in all regions, with a point of change between 2008 and 2015 in each region. In Japan, there is a declining trend in grain intake, especially the intake of rice and rice products, while the intake of wheat and wheat products is increasing ${ }^{1)}$. The intake of grains has a higher contribution than intake of other foods to energy intake and carbohydrate intake (energy intake: $760 \mathrm{kcal} / 1,914 \mathrm{kcal}$ and carbohydrate intake: $157.9 \mathrm{~g} / 256.9 \mathrm{~g})^{1)}$. The contribution to carbohydrate intake is higher in rice and rice products than in wheat and wheat products (rice and rice products: 513 kcal/1,914 kcal and wheat and wheat products: 229 $\mathrm{kcal} / 1,914 \mathrm{kcal}$ for energy intake, and rice and rice products: $113.3 \mathrm{~g} / 256.9 \mathrm{~g}$ and wheat and wheat products: 41.2 $\mathrm{g} / 256.9 \mathrm{~g}$ for carbohydrate intake ${ }^{1)}$. Therefore, decreases in energy intake may have been observed in some regions due to a decrease in grain intake, especially due to the decrease in the intake of rice and rice products. Moreover, due to a decrease in intake of rice and rice products that contribute largely to carbohydrate intake, there may have been points of change in carbohydrate intake throughout Japan between 2008 and 2015. In contrast, the annual trend in fat intake increased in all regions. This increasing trend appears to reflect an increase in the intake of meats and milk that contributed to fat intake in the last 15 years from 2003 to $2017^{1}$. Protein intake significantly decreased in the eastern region from Hokkaido to Kinki I in Japan, but did not show a significant annual change in trend in the west from Kinki II to Minami-Kyusyu. The contributions of grain, meat and fish, and milk and dairy products to the protein intake (70.5 g) were $15.2 \mathrm{~g}, 15.3 \mathrm{~g}, 13.1 \mathrm{~g}$, and $4.5 \mathrm{~g}$, respectively ${ }^{1)}$. Our previous study that investigated the long-term trends from 1995 to 2016 across Japan has shown that the protein intake is decreasing ${ }^{2)}$. There is a need for continued monitoring as regional trends from the present study may be due to local characteristics such as the differences in the changes in intake of fish, meat, and grain that contribute to animal- and plant-based protein intake. The annual trend in salt intake decreased in all regions from 2003 to 2017. In East Asia, particularly in Japan, higher salt intake (compared to those in Western countries) is a public health problem ${ }^{12)}$. Population based projects aimed at reducing salt intake at the national level, local government regions, and food companies in Japan may have led to a decreasing trend in salt intake ${ }^{13)}$. No change in trend in vegetable intake was observed, except for the decreasing trend in Hokuriku and Kanto II. The annual trend in fruit intake greatly decreased in many regions from 2003 to 2017. In the Health Japan 21 (second term), the target of vegetable intake for adults was set at $350 \mathrm{~g} / \mathrm{day}^{3)}$. In addition, this policy aims to reduce the proportion of people who consume less than $100 \mathrm{~g}$ of fruit to $30 \%{ }^{3)}$. However, the mean vegetable and fruit intake in most regions does not meet the target amounts at present; thus, a more sophisticated approach is needed to increase vegetable intake in the current population.

\section{Conclusions}

In Japan, annual trends in intakes of energy, protein, vegetables, and fruits differed among regions from 2003 to 2017. Our finding may be attributed to the differences in health and nutrition policies between the local governments. The NHNS continuously monitors the people's 
health status, nutritional intake, and lifestyle habits. In addition, the NHNS contributes to monitoring the status of health policies such as the Health Japan 21 (second term) ${ }^{3)}$ and the Basic Plan for Promotion of Shokuiku ${ }^{14)}$, and provides basic data for the development of Dietary Reference Intakes for the Japanese ${ }^{15)}$. Regional trends in dietary intake among the Japanese need to be monitored continuously, so that the local governments can use the data from the regional annual trends, and make effective plans for health promotion measures by comparing the results of the trends in Japan.

\section{Conflict of Interest}

There exist no items constituting a conflict of interest.

\section{References}

1) National Institutes of Biomedical Innovation, Health and Nutrition: The National Health and Nutrition Survey Japan, 2017 (2019) Dai-ichi Shuppan Co. Ltd., Tokyo

2) Saito, A., Imai, S., Htun, N.C., et al.: The trends in total energy, macronutrients and sodium intake among Japanese: findings from the 1995-2016 National Health and Nutrition Survey, Br. J. Nutr., 120, 424-434 (2018)

3) Ministry of Health, Labour and Welfare: Health Japan 21 (second term) (2012) Ministry of Health, Labour and Welfare, Tokyo

4) Ministry of Health and Welfare: The National Nutrition Survey Japan, 1956 (1957) Ministry of Health and Welfare, Tokyo

5) The Japan Dietetic Association and Kenko Eiyo Joho Kenkyukai: Nutrition Trends in the Showa Period after the
Second World War: A Review of 40 Years of the National Nutrition Survey (1998) Dai-ichi Shuppan Co. Ltd., Tokyo

6) National Institutes of Biomedical Innovation, Health and Nutrition: The National Health and Nutrition Survey Japan, 2012 (2016) Dai-ichi Shuppan Co. Ltd., Tokyo

7) National Institutes of Biomedical Innovation, Health and Nutrition: The National Health and Nutrition Survey Japan, 2016 (2018) Dai-ichi Shuppan Co. Ltd., Tokyo

8) Ikeda, N., Takimoto, H., Imai, S., et al.: Data Resource Profile: The Japan National Health and Nutrition Survey (NHNS), Int. J. Epidemiol., 44, 1842-1849 (2015)

9) Ministry of Health, Labour and Welfare: Ethical Guidelines for Medical and Health Research Involving Human Subjects (2015) Ministry of Health, Labour and Welfare, Tokyo

10) Ministry of Health, Labour and Welfare: Vital Statistics, 2010 (2011) Ministry of Health, Labour and Welfare, Tokyo

11) Kim, H.J., Fay, M.P., Feuer, E.J., et al.: Permutation tests for joinpoint regression with applications to cancer rates, Stat. Med., 19, 335-351 (2000)

12) Powles, J., Fahimi, S., Micha, R., et al.: Global, regional and national sodium intakes in 1990 and 2010: a systematic analysis of $24 \mathrm{~h}$ urinary sodium excretion and dietary surveys worldwide, BMJ Open, 3, e003733 (2013)

13) National Institute of Biomedical Innovation, Health and Nutrition: Health Japan 21 (second term) analysis and assessment project (2012) National Institute of Biomedical Innovation, Health and Nutrition, Tokyo

14) Ministry of Agriculture, Forestry and Fisheries: Basic Plan for Promotion of Shokuiku (2016) Ministry of Agriculture, Forestry and Fisheries, Tokyo

15) Ministry of Health, Labour and Welfare: Dietary Reference Intakes for Japanese, 2020 (2019) Ministry of Health, Labour and Welfare, Tokyo

(Received February 14, 2020; Accepted June 10, 2020) 


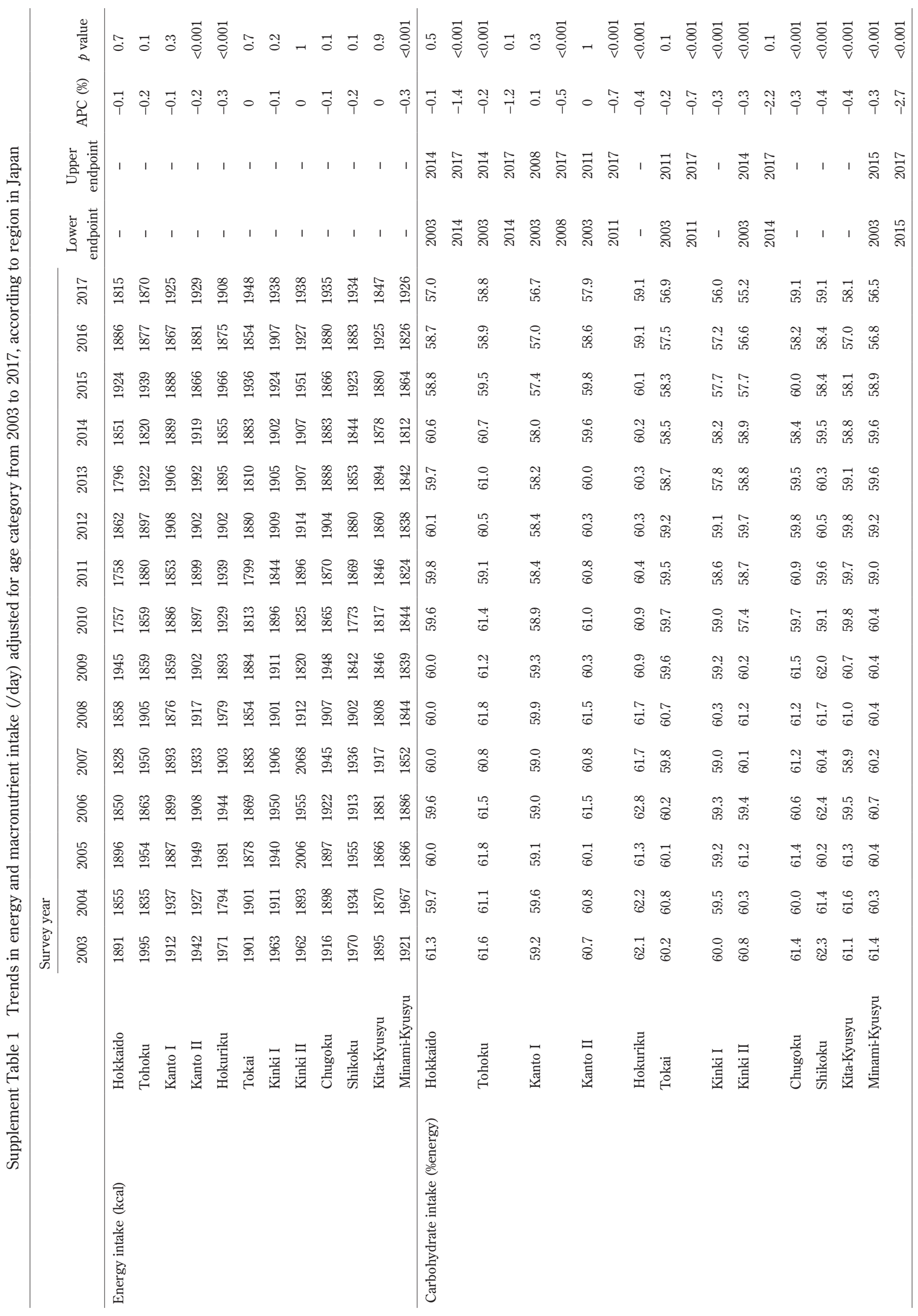




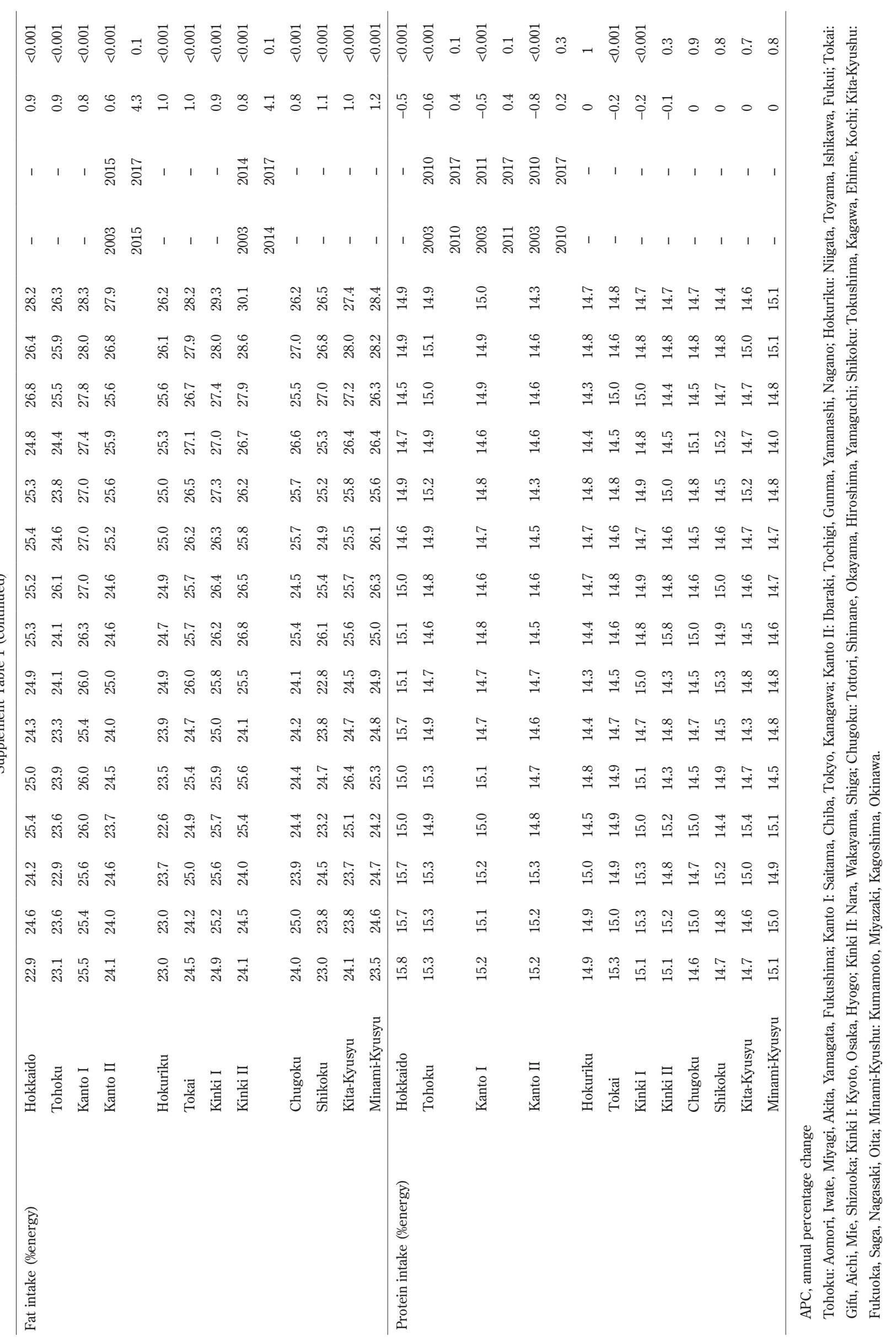




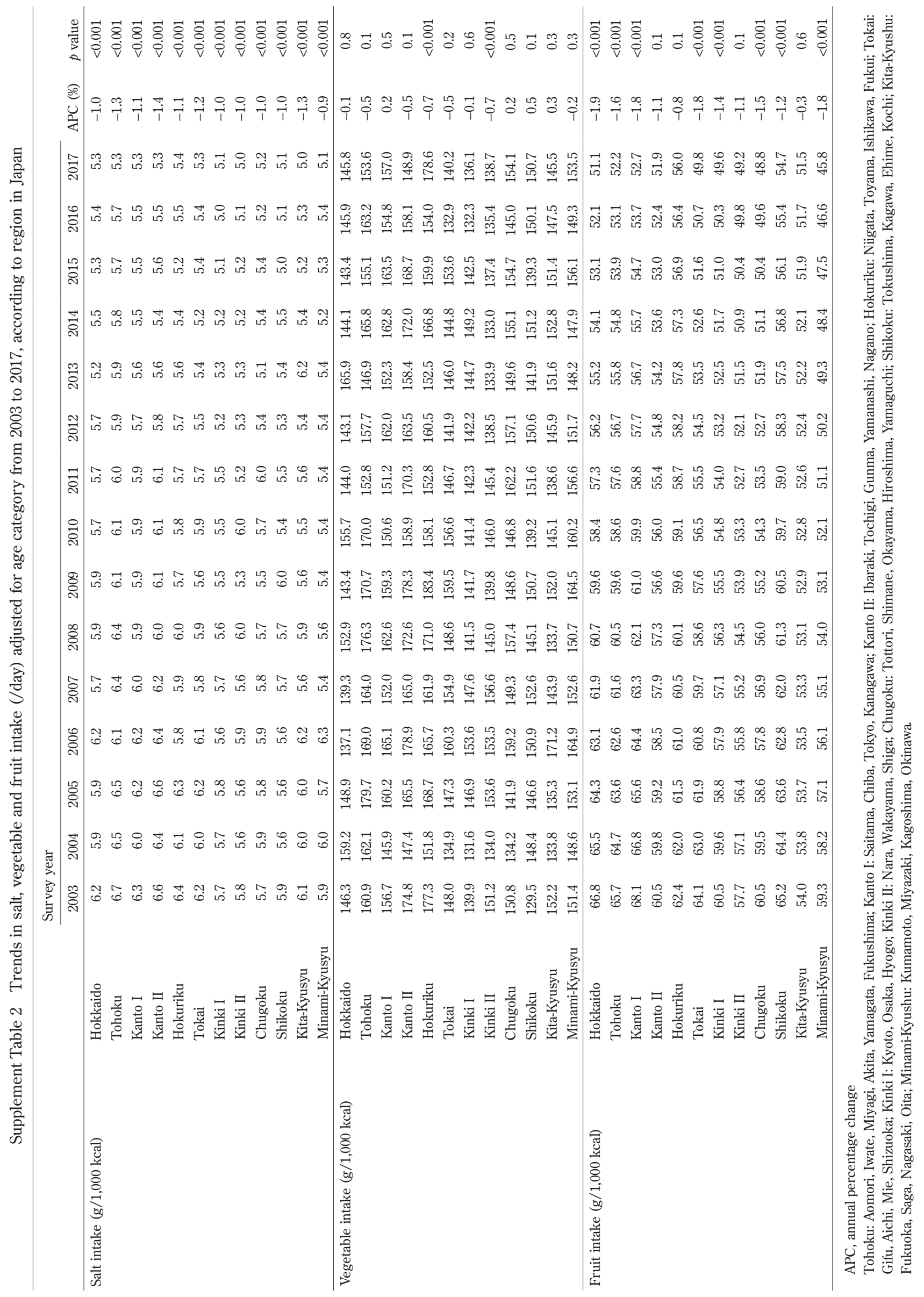




\title{
日本人の地域別栄養素および食品群別摂取量の年次推移 -2003 2017年国民健康・栄養調查一
}

\author{
岡田恵美子，岡田 知佳，松本 麻衣 \\ 瀧本 秀美
}

国立研究開発法人医薬基盤健康 · 栄養研究所国立健康 - 栄養研究所栄養疫学 ·食育研究部 国民健康・栄養調査研究室

【目的】 日本では，体格や生活習慣に関する都道府県間の健康格差が報告されているが，それらの年次推 移は明らかにされていない。本研究では，日本人の地域別の栄養素および食品群別摂取量の年次 推移を調査することを目的とした。

【方法】解析対象は2003 2017年国民健康・栄養調査に参加した 20 歳以上の日本人 140,817 人とした。半科 量式食事記録法を用いて世帯単位の 1 日分の食事調査が実施された。47都道府県は12の地域ブロッ クに区分した。エネルギー，炭水化物，脂質，たんぱく質，食塩，野菜，果物摂取量の年齢調整 值は回帰分析で推定し，2003〜2017年の傾向性の検定には Joinpoint Regression Program を用い た。

【結果】炭水化物と食塩の摂取量は全ての地域において有意な減少傾向を認めた一方で, 脂質摂取量は有 意な増加傾向を示した。たんぱく質摂取量は約半分の地域で, 果物摂取量は 3 分の 2 の地域で減 少傾向を認めた。エネルギーと野菜摂取量は一部の地域で減少傾向を認めたが，ほとんどの地域 で有意な変化はみられなかった。

【結論】2003〜2017年のエネルギー，たんぱく質，野菜，果物摂取量の年次推移は，地域により異なる結 果を示した。これらの結果は地方自治体間の健康・栄養施策の違いによる可能性があるため，今 後も日本人の地域別の栄養素および食品群別摂取量を継続的にモニタリングしていく必要がある。

栄養学雑誌, 78(Suppl) S16～S26（2020)

キーワード : 栄養素摂取量, 食品群別摂取量, 食事調査, 国民健康 - 栄養調査, 日本 